\title{
Psikolojide Kavramlar ve Üstün/Özel (Zekâ, Potansiyel, Yetenek) Kavramına Psiko-Felsefî Açıdan Bakış
}

\author{
OSMAN SEZGIN
}

\author{
Cümleler doğrudur sen doğru isen, \\ Doğruluk bulunmaz sen eğri isen \\ Yunus Emre \\ "Devletin ıslahı için vazife başına gelseniz \\ yapacağınız ilk iş nedir?” diye sorulduğunda \\ verdiği cevap: "Her şeyden önce isimlerin \\ düzeltilmesine bakarım." \\ Konfüçyüs
}

Kavram kargaşası giderilmeden, sağlıklı ve doğru düşünülemez. Dolayısıyla anlamlı tartışmalar ve çözümler üretilemez.

Platon

Özet

Kelimeler ve kavramların doğru ve yerinde kullanımı bilimsel yolun sağlıklı kurulabilmesi için öncelikli şartlardan biri olarak görülür. Bilimlerin, kuramların, yöntemlerin ve kavramların ait olduğu kültür, toplum ve hatta bunları kuran ve kullanan kişilerin psikolojik durumlarının yanı sıra söz konusu toplumun ve kültürün geçirdiği tarihsel süreç de bu konuda çok önemli bir belirleyicidir. Herhangi alanın kelime ve kavramlarında bulunan karmaşa, alanın kendisini de aynı yönde etkileyeceği için o alanın bilimsel gelişimini sekteye uğratabilir. Bu doğrultuda üstün zekâ, üstün yetenek, özel yetenek, üstün ve potansiyel gibi farklı kavramların hemen hemen aynı anlamlarda kullanılmasıyla oluşan

- ARASTIRMA MAKALESI-

OSMAN SEZGIN, osezgin@marmara.edu.tr

Marmara Üniversitesi

ORCID: https://orcid.org/0000-0003-4850-5705

Gelis Tarihi 28.09.2020 • Kabul Tarihi 19.11.2020

doi: https://doi.org/10.47646/CMD.2020.210 
kavram karmaşasının bu bilimsel alana yansıması, pek çok açıdan gelişimi etkilemektedir. Bu makalede, bu kavramlardaki karmaşanın kültürel psikoloji bağlamında tartışılması ve böylece hâlihazırda anaakım psikolojide yer almayan fakat konu ile alakalı olan 'akıl' gibi kavramların ve türlerinin kültüre duyarlı bir bakış ile tasnifi ve irdelenmesi amaçlanmaktadır.

Anahtar kelimeler: Üstün zekâ, özel yetenek, akıl, potansiyel, kavram karmaşası

\begin{abstract}
Correct and appropriate use of words and concepts is considered as one of the primary conditions for the logical progress of the scientific process. The culture and society to which the sciences, theories, methods and concepts belong, even the psychological conditions of people who founded and used them and the historical process of the society and culture in question are also very important determinants in this regard. The confusion in the words and concepts of any discipline may disrupt the scientific development of that field as it will affect the discipline itself in the same way. Accordingly, the reflection of the concept confusion, which is formed by using different concepts such as 'gifted', 'talented' and 'potential' almost in the same meanings, affects the development adversely in many ways. In this article, it is aimed that the complexity should be discussed in the frame of cultural psychology and by that way the phenomenons and the kinds which aren't still in the mainstream psychology but related to the subject like 'reason' should be ordered and examined in cultural sensitive.
\end{abstract}

Keywords: Gifted, talented, reason, potential, consept confusion

\title{
Giriş
}

Her açıdan ve her alanda ve bilhassa bilimsellikte başarılı, özgün (orijinal) ve öncü (aksiyoner) olabilmek için evvela kendi lisanını, bilahare farklı lisanları da çok iyi bilerek zengin bir kelime ve kavram hazinesine sahip olmanın önemi genel olarak kabul gören bir husustur. Öte yandan kelime ve kavramlar arasındaki farklar, sınırlar ve geçişlilikler de bir o kadar berrak olmalıdır ki bilimsel başarı mümkün olabilsin. Meselâ Amerika Kızılderililerinin bir zamanlar duman işaretleri ile iletişim kurdukları bilinmektedir. Bu iletişimle gönderdikleri mesajların tam içeriği bilinemese de felsefî bir tartışma veya bilimsel bir çalıştay yapılamadığı rahatlıkla tahmin edilebilir. Duman halkalarının, varoluşun niteliği ile veya psikoterapi ile ilgili fikirleri yansıtabilecek muhtevada olmadığı açıktır. 
Ancak bu içeriğe sahip olsaydı bile, bir Cherokee filozofu daha ikinci aksiyomunu iletmeye veya bir Cherokee psikoloğu daha ikinci terapisini gerçekleştirmeye geçmeden önce elindeki bütün odunlarla battaniyeleri tüketmiş olurdu (Postman, 1994). Buradan hareketle bilim yapabilmek, yaratıcı olabilmek, felsefe ve bilhassa bilim felsefesi alanında ilerleyebilmek için zengin bir kelime ve kavram hazinesine sahip olmanın gerekliliği hatta zarureti görülebilir. Morin'e (1999) göre de aynı kelimelerden ayrı manâlar anlayanlarla, ayrı anlamları aynı kelimelerle ifâde edenlerin doğru bir iletişim kurabilmeleri mümkün görünmemektedir.

Zengin bir kelime haznesine sahip olmak ve birden fazla lisanı akademik seviyede bilmek kadar bilimlerin, kuramların, yöntemlerin ve kelimelerin ait olduğu kültür, toplum ve hatta bunları kuran ve kullanan kişilerin psikolojik durumlarının yanı sıra söz konusu toplumun ve kültürün geçirdiği tarihsel süreç ve bağlam da bu konuda çok önemli rol oynar. Bilimlerin, kuramların ve kelimelerin doğru anlaşılabilmesi için sosyolojik, psikososyal, sosyopsikolojik açıdan doğduğu kültürü ve o kültürün ait olduğu toplumu da çok iyi bilmek gerekecektir. Zira bilimler, kuramlar ve kelimeler bir taraftan ait olduğu kültürün taşıyıcısı konumunda olurken öte yandan ait olduğu kültürün ve toplumun malıdır şeklinde bir anlayışın varlığı gözden ırak tutulmamalıdır.

Bunun yanı sıra tarihsel seyir içinde belli değişimlere uğrayan kavramlar, kullanan kişiye, kullanıldıkları ortama ve kullanılma niyet ve amacına göre farklı anlamlara evrilebilen bir nitelik gösterirler. Hatta bu dönüşüm göz ardı edilirse herhangi bilgi-kavram manzumesine anlam kazandırabilmek çok güçleşir. Fakat bilgi ve kavramlar için yapılan bu vurgu, kültürel bir görecelilik önerisi ile bilgi-kavram manzumelerini objektif inceleme gerekliliğini ortadan kaldırmaz. Aksine, bu perspektifin, evrensellikle görecelilik arasına sıkışıp kalmış "batılı" ikiciliğin ötesine geçmek için bir imkân sağlayabileceği düşünülmelidir. Bilimsel objektiflik için güncel bilginin, kavramların ve kuramların tarihî, toplumsal, psikolojik ve kişisel serencâmına vâkıf olmak ve bunun da ötesinde kendine has hayat telakkisinin konumlanışının şuurunda olmak temel bir adım olarak telakki edilir hâle gelmiştir. Günümüz bilimselliği evrensel geçerliliği olan objektif bilgi üretmenin dayandığı bazı maddi şartlara bağlılığıyla bilinmektedir. $\mathrm{Bu}$, "batı"nın en büyük zaaflarından biri olarak görülen sınıflı parçalı olma özelliği ile ilişkilidir. Derin tarihî bir arka plana sahip olan bu yapısal özellik, her alanda olduğu gibi bilgi/bilim bağlamında da kendini göstermektedir (Özdemir, 2004).

Bütün bunlar değerlendirilirken unutulmamalıdır ki "doğu-batı” olarak kurgulanan ikircikli yapı, "batılı" düşünce ve bilim geleneğinin bir ürünüdür.

Psikolojide Kavramlar ve Üstün/Özel (Zekâ, Potansiyel, Yetenek) Kavramına Psiko-Felsefî Açıdan Bakıș 
Bir başka ifade ile batıyı doğu karşısında tanımlayan en temel özelliklerin batılı bilim ve siyaset yapma tarzının Avrupa merkezli, dolayısıyla iddia edildiği gibi objektif değil de tam aksine yanlı tabiatı olduğu söylenebilir. Karşıtlığa varacak derecede iki zıt evren olarak kavramlaştırılan ve sadece zıtlaşmacı-çatışmacı yaklaşımın ürünü olmasıyla bile genelgeçer ve evrensel bir tipleme olduğu ileri sürülemeyecek olan bu kurgu, politik planda batının dünya hegemonu hâline gelmesine, bilimsel planda da deneysel-pozitivist geleneğin hakimiyetine bağlı olarak meydana gelmiştir. Materyalist monist felsefe ve indirgemeci bir yöntem bu durumun arka planını oluşturmaktadır. Uzlaşmacı ilişki arayışı, ayrışmış çıkarlar temelinde katı bir şekilde tanımlanmış güçlü siyasal kimlikler tarafından dezavantajlı grubun teslimiyeti olarak anlamlandırılır. Bu durumu oluşturan zihniyetin niteliklerinden biri, batının hayat alanını tanımlayan güçlü, kapalı, dışlayıcı kimlik algısıdır. Aynı zamanda bir başka nitelik ise tarihselliğin ve toplumsallığın dışlanması veya en iyi ihtimalle ihmal edilmesine de yol açan kategorik ve statik tanımlamalar aracılığıyla düşünmedir. 'Ben ve öteki' benzeri zıtlıklar ve dikotomilerle kurulan çatışmacı ve zıtlaşmacı ilişkiler, bunların sonucunda ortaya çıkan açık rekabet ve çatışmaları meydana getiren siyasal, toplumsal, iktisadi, psikolojik oluşumlar da yine batıyı inşa eden niteliklerdendir. Batının önemli nitelikleri arasında erkek, katı, dışlayıcı, otoriter, hiyerarşik, sınıflı, materyalist monist ve indirgemeci olmasının merkezî bir rolü vardır. Bu özellikleriyle egemen güç olma konumunu hâlihazırda sürdürdüğü ölçüde "batı", hepimizin içinde yer aldığımız "hegemonik güç ve paradigma"nın ister istemez temsilcisi olarak varlığını sürdürmektedir. Bu durum çoğunluk dünya da dahil olmak üzere batıyı zorunlu bir referans ve ölçü noktası olarak özel ve ayrıcalıklı bir konuma oturtmaktadır. Dolayısıyla batıyı oluşturan nitelikleri düşünerek bugünü değerlendirmek zorunlu konumumuz itibariye önem arz etmektedir (Özdemir, 2004).

Yukarıdaki açıklamalar ışı̆̆ında bilim ve yöntemini, bilim felsefesini ve özellikle psikoloji bilimini, psikolojik kuram, kavram ve mefhumları incelemek gerek objektiflik adına ve gerekse evrensel bir başarıya ulaşmak adına elzemdir.

\section{Kavramlar ve Karmaşa}

Günümüz psikolojisinin özerk bir bilim olma yolundaki gayretleri, bilim tarihi açısından henüz görece kısa sayılabilecek bir süreye sahiptir. Neredeyse yirminci yüzyılın başına kadar felsefe, din, edebiyat ve tıp ile beraber yürüyen psikoloji ancak bu tarihten itibaren özerk bir bilim 
sayılmaya başlamıştır (Maher ve Spitzer, 1998; Schultz ve Schultz, 2007). Özerk bir bilim olma yolunda ilerleyen psikolojinin bu çok kısa geçmişinde, bir taraftan sadece teorik değil, aynı zamanda pratiği olan bir bilim olma gayretlerinin getirdiği yeni kelime ve kavram ihtiyaçlarını karşılamada zorluklar yaşanmaktadır. Ayrıca kelime ve kavramlarını iki bin yıl hâkimiyetinde kaldığı felsefenin tesirlerinden kurtararak inceleme ihtiyacı karşısında yaşadığı zorluk, söz konusu bilim alanını bir hayli müşkül durumda bırakmaktadır. İncelenmesi gereken kavramlar, bu özerklik mücadelesi ile karıştırılarak karmaşık bir hâl yaratabilmektedir. Meselâ irâde (volition) kelimesini bir örnek olarak verebiliriz. Felsefede ve eğitim felsefesinde irâde ve irâdecilik (voluntary, voluntourism) kullanılırken, günümüz psikolojisinde yönetici işlevlerle beraber irâdeden çok nadir olarak daha yeni söz edilmeye başlanmış olması konu hakkında bir fikir verebilir (Sezgin, 2013a; Sezgin, 2013b). Bir diğer örnek olarak zihinsel özellikler açısından yelpazenin her iki ucunda yer alan bireylerin tamamının genelde anormal olarak ifâde edilişi bu açıdan irdelenebilir. Batı Avrupa ve Kuzey Amerika kökenli psikoloji ve psikolojik danışmanlıktaki üstün zekâ, çoklu zekâ, üstün yetenek, üstün potansiyel, özel yetenek gibi kavramlardaki karışıklık, normal kavramı ve anlayışıyla de ilintili olması münasebetiyle normal kavramının incelenmesi önem arz etmektedir. Normal kavramındaki karışıklığı incelemek zekâ ve ilgili kelime ve kavramlardaki karışıklığı daha iyi anlamayı temin edebilir.

Normal kavramı özellikle üstün olandan bahsedilirken bir hayli zor anlaşılabilen kavramlardan (mefhumlardan) biri olabilir. Meselâ herhangi bir sınıfta derse giren bir öğretmen, öğretmenler odasına geldiğinde derse girdiği sınıftan bahsederken "derse girdiğim bu sınıfta iki tane özel öğrenci veya iki tane anormal (abnormal) öğrenci var" demiş olsa, bu durumda bu iki anormal öğrenciden neyi kastettiğini nasıl anlayacağız? Normal altı için -subnormal- kelimesini kullanmış olsun (Budak, 2009). Normalüstü zekâya sahip olan öğrenci için hangi kelimeyi kullanmalıdır? Normalin altı ve normalin üstü için aynı kelimeyi kullanmış olsa yani "anormal iki öğrenci var" demiş olsa bu durumda bu cümleden ne anlaşılacak? İşte bu kargaşayı önlemek için paranormal kelimesi ele alınabilir. Normal altı ile normal üstünü ayırt edecek anormal ve paranormal kavramlarını kullanmak, zekâ geriliği ile üstün zekâyı ayırt ederken bunun kolayca ifâde edilebilmesine ve yanlış anlaşılmayı asgariye indirmeye imkân sağlayabilir (Sezgin, 2013b).

Fenomenleri, özellikle psişik fenomenleri sınıflandırırken, psikolojik olanlara "normal", patolojik olanlara "anormal" yani normal olmayan demek kâfi gelmemektedir. Normal olmayan; fakat patolojik anlamında a-normal de kabul edilmeyen bir başka psişik fenomenler kategorisi var ki

Psikolojide Kavramlar ve Üstün/Özel (Zekâ, Potansiyel, Yetenek) Kavramına Psiko-Felsefî̀ Açıdan Bakış 
bunlara da paranormal denilebilir. 'Para' ön takısı 'karşı' anlamından başka 'yanında, komşusu' anlamlarını da ifâde eder. Paranormal denilince normalin komşusu, normalin yanında oluşan, fakat alışılmış (mûtad) olmayan, sık rastlanılmayan kastedilmektedir. Normal, istatistik kânunu tarafından "vasatî, ortalama" olarak tanımlanmaktadır. Bu hâle göre anormal manâsına patolojik, vasatîden yani, ortalamadan basit bir inhiraf (sapma) olarak anlaşılır. Paranormal kelimesinin daha iyi anlaşılabilmesi için psikolojideki kavramların sınıflandırmasına ve normal kavramının menşeine bakmak açıklayıcı olacaktır. Norm, "norme” kökünden, Latince gönye, cetvel anlamına gelen bir kelimedir. Bu anlamı ile kânuna hizmet eden, kâideye elverişli prensip anlamındadır. Buna göre norm tip, model ve kâide demektir. Normal ise kâideye uygun, uyan, mûtad, olağan demektir. Matematikteki anlamı ise amudî, dikey demek olur (Neufeldt ve Guralnik, 1988).

Normal kavramını anlayabilmek için önce psikolojideki ve psikopatolojideki mefhumlar (notion), bu kavramın taşıdığı değer öncelikli olarak nicel (kantitatif, kemmî) ve nitel (kalitatif, keyfî) olmak üzere iki bölümde incelenir. Nitel kavramlar evvela negatif ve pozitif değerler diye ikiye ayrılır. Kantitatif kavramlar psikolojide görünüşü itibari ile kendini bir ölçü ile ifâde ederek istatistik ve gradüalist olmak üzere iki kategoride mütalaa edilir (Doksat, 1975). İstatistik kavram sağlıklı olmayı normal, sağlıklı olmamayı da anormal olarak kategorize eder. İstatistikteki normali değerlendirmek için meşhur çan (gauss) eğrisi kullanılır. Normalin psikolojideki anlamları birkaç şekilde ifade edilir. Bir ferdin (bireyin) karakteristikleri, normali gösteren eğrinin dışında değilse ve mensup olduğu toplumun değişim çeşitliliklerinin sınırları içinde bulunuyorsa, o ferde normal denir. Bir diğerinde, bir bölüştürme, bir dağıtma (tevzi, distribution) eğrisi eğer Gauss Eğrisi'ne uygunsa o eğri normali gösterir. Üçüncü tanımda, ortalama bir tip veya karakter de normal olarak nitelendirilir. Dördüncü tanımda ise bazen ideal bir tipe de normal adı verilir. Normalin sıhhatlilik ve anormalin patoloji ölçüsü olup olamayacağı, olursa ne dereceye kadar itibar edilebileceği düşündürücü bir noktadır. Bu açıklamalar ışığında üç türlü normallikten söz edilebilir. Bunlar istatistik normalite, ideal normalite ve fonksiyonel normalitedir (Sezgin, 2013b) ${ }^{1}$.

İstatistik normallik, toplumsal (içtimâî, sosyal) norma uygun oluş ve sık rastlanış ile aynı anlamda kullanılmaktadır. Fakat yalnızca niceliksel olan normal ölçüsü kolaylıkla reddedilebilir. Öyle hâller vardır ki bu ölçü geçerli 
sayılmaz. Meselâ ender rastlanan dâhîleri normlara uymadığı için anormal ve neticede patolojik kabul etmeye imkân var mıdır? Kızamık hastalığının da sık rastlandığı için normal mi kabul edilmesi gerekir? İdeal normalite, genellikle kökeni toplumsal olan bir anlayıştır. Bir toplumun ideal saydığı tipe uygun olanlar, ideal normaldir. İdeal norm, toplumdan topluma değişecektir. İstatistik normalite ile ideal normalite birbirinden bağımsız değillerdir. Bir davranışın normdan sapışı, uzaklaşışı hususundaki sübjektif intibâ o davranışın enderliği nispetindedir, yani nâdir oluşu ile orantılıdır. Fonksiyonel normalitede ise normal ölçüsü bir ferdin (bireyin) varmak istediği hedeflere, gâyelere ve karakteristiklerine uygun düşen bir hâlde olmasıdır (Sezgin, 2013b). Anlaşılacağı üzere sıhhatliliğin ölçüsü olarak normalin çeşitleri yeterli sayılmamaktadır. Bu durumda normalin ölçüsünü daha farklı bir şekilde bulmak, genişletmek ihtiyacı zorunludur denilebilir.

\section{Kavramlar ve Anlamlar}

Normal kavramındaki karışıklığa ve yetersizliğe bir nebze temas ettikten sonra bu bağlamda "üstün" olarak nitelenen çocukları ifade eden kavram karmaşasına da değinilmelidir. Türkçede bu alanda kullanılan kelime ve kavramlar, üstün zekâ, çoklu zekâ, üstün yetenek, çoklu yetenek, üstün potansiyel, özel yetenek v.b. şeklinde ifade edilmektedir. İngilizcede ise "intelligence", "mind", "reason", “wisdom”, "gifted”, “talented”, “ability” v.b. kelimelerin kullanıldığı görülmektedir.

Bu konuda günümüz psikolojisinde kelimelerde olduğu gibi anlamda da bir birlik söz konusu değildir. Zekâ kelimesinden her paradigmanın ve hatta her kuramın kendine göre bir anlam çıkardığı ve çok farklı şeyler söylediği görülmektedir.

İlk ve en önemli mesele/sorun "zekâ nedir?" sorusu ile buna verilecek cevaptır denilse abartılmış sayılmaz. Henüz hangi kelime ile ve neyin kastedildiği konusunda bir berraklık yok iken, anlamda birliğin olabilmesi mümkün müdür? Ayrıca insanlar arası bir farklılığın olduğu hissedilip ama onun kapsamı belirlenemez ise veya üzerinde ittifak edilen bir içerik tespit edilemez ise ne söylenilmek istenildiği, nasıl anlatılıp, nasıl geliştirilecektir? Ayrıca söz konusu alanda doğru kelimeyi bulmak ve muhtevasını doğru belirleyerek olması gereken tanımını yapmak başarı için yeterli mi olacaktır?

Tarih boyunca birtakım insanların tarihe not düşmeleri, unutulmaz eser vermeleri, keşif ve icatta ileri seviyede olmaları, günümüz psikoloji literatürüne göre yaratıcılıklarının olması v.b. durumlar anlatılırken kullanılan çeşitli kavramlar da bu karmaşaya katkı sağlamaktadır. Mesela 
Sokrat, Eflatun, Aristo, Konfüçyus, Buda, Fârâbî, İbn Sina, Gazzalî, dünyadaki ilk üniversite kabul edilen Karaviyyin Medresesini 859 yılında Fas Krallığı'nda kuran Tunus doğumlu Müslüman ilim adamı Fatma el-Fihrî, Mevlânâ, Yunus Emre, Mimar Sinan, Einstein, Newton, Van Gogh, Mozart, Da Vinci v.b. kişiler hangi kavram ile niteleneceklerdir? Pek çok yerde bu kişilerden zekî, dehâ, üstün yetenekli, yaratıcı kavramları kullanılarak bahsedilir. Bu terimlerin birlikte anılması kavramların/mefhumların birbirine karıştırılmasına ya da birbirlerinin yerine yanlış kullanılmasına yol açmaktadır.

Bir diğer sorunun da zekî, dâhî veya yaratıcı olarak gösterilen bireylerin efsaneleştirilmesi, durumlarının abartılması olduğu söylenebilir. Bu tür yaklaşımların, çoğunluğun, bu hikâyelerdeki insanları özel olarak nitelendirmelerine ve böylece yaratıcılık, yetenek veya zekâ kavramlarını kendilerinden çok uzakta görmelerine sebep olduğu söylenebilir. Bu anlayış diğer insanların motivasyonuna olumsuz tesir edebilir. Ayrıştırma ve ötekileştirme gibi psikolojik-psikososyal bozuklukları ve toplumsal problemleri ortaya çıkarabileceği de düşünülmelidir.

Burada çok önemli bir sorun da "üstün" olarak nitelenen çocukların/ bireylerin, gerek aldıkları eğitim esnasında ve gerekse ebeveynleri gibi sosyal çevre unsurları tarafından damgalanmalarıdır (stigmatize). Bu vesileyle egoist, egosantrik özelliklerden narsisistik kişilik yapısına kadar uzanan bir skala ortaya çıktığı gözlenmektedir. Bu sıkıntı, şu âna kadar günümüz psikoloji anlayışı ile maalesef çözüme yaklaşamamaktadır. Bununla birlikte "üstün" diye nitelenen çocuklardan beklentilerin yüksek olmasından dolayı, yüksek kaygı, duygudurum bozukluğu v.b. psikolojik rahatsızlıkların da görülebilmesi önemli bir ihtimaldir.

Zekânın görevi nerede başlar ve nerede biter? Şayet başarı için zekânın yanı sıra akla da ihtiyaç varsa aklın etkisinin, görevinin sınırları nereye kadardır? Akıl ve zekânın yanı sıra zihni nereye koymamız gerekir? Günümüz psikolojisi akıldan bahsediyor mu? Neden ve niçin akılla ilgili bir ölçek söz konusu değil? Ölçülemeyen şeyin bilimi olmazsa, o takdirde akıl ölçülemiyor diye yok mu sayılmalı? Akıl dikkate alınmaz ise o takdirde bütün yük, görev ve sorumluluk zekâya yüklenmiş olmaz mı? Bütün yük zekâya yüklenirse bu doğru bir yaklaşım olur mu ve zekâ bu yükü kaldırabilir mi? Bu ve benzeri soruları daha da çoğaltmak mümkündür.

Fakat yukarıdaki sorulara ilave edilebilecek en önemli soru, akıl ve zekâyı doğru ve yerinde çalıştırabilmek için başka şeylere ihtiyacımız olup olmadığıdır. Mesela irade gerekli mi? İradesi zayıf birinin zekâsı veya aklı zirvede olsa acaba bunun yaratıcılığı veya akademik başarısı hangi seviyede 
olur? Duygu yönetimi ve düzenlemesi zayıf olan bir insan, zekâsını ve aklını doğru kullanabilir mi? Soruları daha da çoğaltmak mümkündür. Bu sorular zekâ konusu düşünülmeye başlandığında mutlaka dikkate alınmalıdır ancak asıl konumuz bu olmadığından yukarıdaki sorular ve cevapları bir başka zamana bırakıp, şimdilik kelime ve kavram olarak zekâ ve paydaşlarına dönmeyi yeğliyoruz.

Zekânın ne olduğu konusunda günümüz anaakım psikolojisinde belirlenmiş kesin bir tanım bulunmamaktadır. Belirgin bir tanım olmamasının yanı sıra pek çok kuramcı tarafından yapılan tanımlamalarda da mutlaka eksik bir yön olduğu görülmektedir. Zekânın tanımı ve sınırlarına ilişkin tartışmalar yıllarca yapılmış ve hâlâ devam etmektedir. 1976'da Robinson ve Robinson zekâ ile ilgili birçok kuramı analiz etmişler ve bu kuramlarda yer alan bilgilere dayanarak zekânın en fazla kullanılan üç özelliğini tespit etmişlerdir. Bunlar, öğrenme kapasitesi yani kişinin verilen eğitimden yararlanabilme kapasitesi, öğrenilmiş bilginin toplamı yani kişinin kendi yetenekleri içinde öğrendiği tüm kavram ve bilgiler ve çevrenin istemlerine uyabilme yani kişinin kendisini çevresine ve çevresinde görülen değişikliklere başarılı bir şekilde uyum gösterebilmesi becerisi olarak bulmuşlardır (Patton, Panna ve Beirne-Smith, 1986 akt. Özekes, 2013). Bugün bakıldığında zekâya dair kuramlarda tespit ettikleri ortak noktaların zekâya ait özel anlamlar içermediği açıktır.

\section{Kavramlar ve Çelişkiler}

Günümüz psikolojisi açısından zekâ ölçümü ile ilgili yapılan ilk çalışma 1890'da Vames McKeen Cattell tarafından gerçekleştirilmiştir. İlk kez bu çalışmada zekâ testi (mental test) kavramı psikoloji literatüründe kullanmıştır (Anastasi, 1972, akt. Özekes, 2013). Dikkat edilirse çalışmada kullanılan kavram 'mental' olarak tercih edilmiştir. Bu çalışmada reason, mind v.s. gibi kavramların kullanılmamış olması çalışmaların başlangıcı adına önemli bir ipucu sunmaktadır. Zekâ ölçümü hakkında yapılan çalışmalar devam ederken başka kavramlar da işin içine katılmıştır. Ebbingshaus 1897 yılında aritmetik hesaplama, bellek uzamı ve cümle tamamlama testlerini okul çocuklarına uygulamış ve cümle tamamlama testinin okul başarısıyla ilişkili olduğunu bulmuştur. Binet ve Simon 1905'te ilk ölçeklerini geliştirmişlerdir. İkinci ölçeklerini ise 1908'de 3-13 yaş arası çocukların zekâ yaşlarını ölçmeye yönelik olarak geliştirmişlerdir. Amerika'da Stanford-Binet testi 1916'da geliştirilmiştir. Stanford-Binet zekâ testi zekâ yaşı ile takvim yaşı arasında bir oranın kullanıldığı (IQ) ilk test olmuştur. Wechsler 1939 yılında yetişkinler için daha önce oluşturulan zekâ 
testlerinin çocuklar için olduğunu ve bunların kullanılmasıyla yetişkinlerin değerlendirmesinin mümkün olmadığını ileri sürerek yetişkinler için bir zekâ testi olan WAIS ölçeğini geliştirmiştir. Wechsler 1950'de WechslerBellevue isimli testin kolay maddelerini alarak geliştirilen çocuklar için zekâ testini (WISC) oluşturmuştur (Anastasi, 1972, akt. Özekes, 2013).

Zekâ ile ilgili kelime, kavram ve kuram karışıklığını artıran bir konu da Gardner'in çoklu zekâ kuramıdır. Bu konu ile ilgili bazı gerçekleri gözden geçirmek faydalı olacaktır. Şöyle ki, Zihin Çerçeveleri: Çoklu Zekâ Kuramı (Frames of Mind: Theory of Multiple Intelligences) isimli kitabının İlk Otuz Yıl başlıklı bölümünde,

“Meslektaşım David Feldman'ın belirttiği gibi zekâ kelimesi seçimi, beni IQ testlerine değer veren ve değer vermeye devam etmekte olan psikolojik kuramla doğrudan yüzleşmeye itti. Ancak Feldman'ın, motivasyonumun "IQ'yu yenme" isteğimden geldiği iddiasına katılmıyorum. Ne belgeler ne de hatırlatıcı kanıtlar böyle bir yüzleşme ile ilgilendiğimi işaret etmektedir."

şeklinde kendisi ile ilgili bir iddiayı ve bu iddiaya dair kendi cevabını nakletmektedir (Gardner, 2017).

Her ne kadar IQ'yu yenme değil yüzleşme gibi bir düşüncesi olduğunu ifade etse dahi, yaşantısında bunun aksini düşündürecek ve Feldman'ı doğrulayacak bir hadisenin olduğu kolayca fark edilebilir. Aynı bölümde Gardner (2017),

"Gençliğimde ciddi bir piyanisttim ve diğer sanat dalları ile de ilgilenmekteydim. 1990'ların ortasında, gelişim ve bilişsel psikoloji üzerinde çalışmaya başladığımda, anahtar ders kitaplarında sayısız bilimsel düşünce tartışmaları karşısında sanata dair en ufak bir atfın dahi yer almaması beni şaşırtmıştı. İlk profesyonel amaçlarımdan biri akademik psikolojide sanata bir yer bulmaktı. Hâlâ daha bulmaya çalışmaktayım."

diye ifade ettiği kısımda yeteneği zekâ olarak adlandırmasının temeli yer almaktadır. Zekâya gösterilen ilgiyi, yetenekleri ile kendisinin de görmek istediği ve bunu hem bilimsel hayatının hem de kuramının temel amacı olarak gördüğü anlaşılmaktadır.

Nitekim aynı bölümde "Büyük bir güvenle söyleyebilirim ki bu kitabı 'Seven Talents' adıyla yazmış olsaydım 'Zihin Çerçeveleri' adı ile görmüş̧ olduğu ilgiyi görmeyecekti” ifadesi (Gardner, 2017), bir yönü ile IQ ile mücadele etmek istediğini ve bunun için yeteneği ön planda tuttuğunu gösterirken öte yandan nesnel, pozitivist ve pragmatist bir hayat anlayışının içinde bulunmasının sonucu olarak niceliksel ifadelendirme üzerine kurulu bir dünyada kuramının ilgi göremeyeceğinden korkmakta olduğu söylenebilir. 
Kendi ifadesi ile kendisi iyi bir piyanisttir, sanatın diğer dalları ile ilgilenmekte ve bu alanda başarılı olmanın üstünlük işareti ve ölçüsü olduğunu düşünmektedir. Bunu nasıl kabul ettirmenin yollarını aramaktadır. Bununla ilgili olarak da kelime oyunu yaptığı görülmektedir. Bu durumu anlatabilmek için kullandığı kelime, kuramının ve de kitabının adı olarak ilk başta düşündüğü kelime "talent" kaabiliyet, yetenek anlamındadır yani zekâ ile ilgili değildir. Kitabın isminde 'mind' yani zihin kelimesini kullanmıştır. Muhtemel endişelerini gideremediğinden kitabın adını koyarken seçtiği kelimelerden birisi de 'intellegence' kelimesidir. Gardner, görüldüğü üzere kitabını yazarken ve kuramını ifade ederken hangi kelime ile neyi ifade etmek istediği konusunda kendisi de bir çıkmazdadır.

$\mathrm{Bu}$ anlatımlarının hepsi bir derlenip toparlanacak olursa toplumsal kabul, onu doğru bildiğini söylemekten alıkoymuş gibi görünmektedir. Bilimsellikten öte 'popülerlik' onu yönlendirmiştir. Bahsedeceği konu için kullanacağı kavram hususunda düşüncesinin netleşmemiş olduğu görülmektedir. Zira teorisini ifade ederken "mind" ve "intelligence" kelimelerini kullanmasının yanı sıra "talent" ve "gifte"' kelimelerinin asıl düşüncesini ifade ettiğini belirtmektedir. Ancak bunları kullanma konusunda çekimser kalmış, şüpheye düşmüştür.

Sonuç olarak Gardner'ın $(1983,1991)$ çoklu zekâ teorisini ortaya atması ile birlikte zekânın pek çok yetenekten oluştuğu görüşünün ön plana çıkmasıyla zekâ ve yetenek kavramlarının iç içe geçtiği görülmektedir.

Gardner'ın zekâyı değil, yeteneği ortaya koyma niyetini ve gayretini kendi kitabından ve hayatından örnekler ile anlatmaya çalıştığımız hususu Amerika'da kurulan ve bu alanda araştırma yapan bir kurumun adında da görebiliriz. "National Association for Gifted Children (NAGC)" isimli kurumun adında görüleceği üzere "gifted" yani 'verilmiş hediye, Tanrı vergisi' anlamındaki sıra dışılık, normal üstünlük ifade eden kelimenin kullanımı, günümüz psikolojisinin kaynağı olan Kuzey Amerika'da dahi zekâ ile yetenek kelimesinin bir karmaşa içinde kaldığını ve söz konusu kavramlara kültürel, bağlamsal anlamlar yüklendiğini göstermektedir.

Göz ardı edilmemesi gereken çok önemli bir konu da lisanlar arası tercümelerde aynı anlamda kabul edilen kelimelerin birebir aynı anlamı taşımadıkları, kültürden kültüre anlamlarının kapsamında ciddi farklılıkların olduğu ve hatta girişte ifade edildiği gibi söz konusu kelimeleri kullanan kişilerin bile kelimelerin anlamında farklılık yarattıkları bir vakıadır.

Felsefeden uzaklaşıp, bilimsel gelenekten kopup (Einstein hariç tutulmak şartı ile), insanlığın binlerce senelik tecrübesini niceliğe yani sayılara fedâ 
eden materyalist monist ve bilimsel indirgemeci bir yöntemle psikoloji kurmaya çalışılınca karşımıza kelime, kavram (concept), mefhum (notion), kuram ve paradigma fırtınaları çıkmaktadır. Bu durum, bir yönü ile bilim ve psikoloji adına çok istekli süreçler ve çalışmaların olduğunu yansıtırken, öte yandan insanlığın asırlar süren birikimlerinin göz ardı edilmesinin fikrî ve bilimsel kaoslar yarattığını, bu durumun da insanı anlama ve kavramada yetersiz kalmaya sebep olduğunu göstermektedir. Eğitimde ve psikolojide bu yüzden çok acı olaylarla yüz yüze gelinmiştir. Davranışçılıktan yapılandırmacılığa geçme örneğinde olduğu gibi psikoloji ve eğitim hızlı bir şekilde nicelden nitele ve somuttan soyuta doğru yol almaktadır.

Üstün zekâ, çoklu zekâ, üstün yetenek, özel yetenek, üstün potansiyel gibi kavramlarla ilgili ifade ve tanım karmaşası günümüz Türkiye'sinde de devam etmektedir. Bu konuda ülkemizde uzun zamandır araştırmalar yapan Sak (2020) da "Üstün Zekâlılar" isimli kitabında "üstün zekânın tanımı konusunda henüz evrensel düzeyde bir uzlaşıya varılmış değil" demektedir. Hem kelime ve kavramlarda hem de anlamda uzlaşı söz konusu değildir. Üstün zekâ ile ilgili tanımlarda bir uzlaşmanın olmamasının neden ve niçinleri ile buna yönelik hangi teklif veya tavsiyelerin sunulacağı çok önemlidir.

\section{Kültüirel Psikoloji Açısından Kavramlar ve Zekâ}

Kavramların incelenmesinde, anlamlandırılmasında, çeşitlendirilmesinde, işleyişin bir parçası hâline gelmesinde kültürler önemli bir etkendir.

Kavramlar kültürden beslenerek yine kültürün içine doğmaktadırlar. Kültürel psikoloji ve kültüre duyarlı psikolojik danışma açısından zekâ ve benzeri kavramlar incelendiğinde Türk kültüründe zekâ ve akıl kelimelerinin beraber kullanıldığı görülmektedir. Başarı, keşif ve icat, şimdi ve şu anki olayları anlamak, kavramak, soyutlamak ve neden niçinlerini tespit etmek için tek başına zekâ yeterli görülmekle birlikte aklın varlığına ve önemine de işaret edilmektedir. Nitekim halk arasında "ne kadar akıllı ve zeki bir insan" diye iki kavram bir arada kullanılmaktadır. Hatta akıl bir kademe daha önde ve daha önemlidir. Burada sadece zekâ söz konusu olduğunda son asırlardaki teknokratların icatlarının nasıl bir değişime sebep olacağının, icatların insanlığın lehine mi aleyhine mi olduğunun düşünül(e)memesi örnek olarak verilebilir. Eğer bu icatlarda akıl da devreye girseydi sonuçları hakkında yapılan yordamalarla icatlar insanlık adına olumlu bir vaziyette olabilirdi. bakmak isabetli olacaktır. Zekâ kelimesi Osmanlı Türkçesinde peltek z (ذ) 
ile (ذكا, ذكاء) şeklinde yazılır. Kelime anlamı olarak "parlama, parlaklık, alev alma, keskin koku, keskin olma" anlamlarına gelen zekâ, kavram olarak ise "dirayet, zeyreklik, anlak, çabuk anlama, çabuk soyutlama; hatayı, yanlışı çabuk bulma" demektir (Çağbayır, 2007; Keklik, 1982). Türkçede parlak zekâ, keskin zekâ, kıvrak zekâ deyişleri de muhtemelen kelimenin parlaklık ve keskinlik anlamlarından esinlenerek kullanılıyor olabilir.

Günümüz psikolojisinde olduğu gibi Türk kültüründe de zekâ şimdiyi ve şu ânı kapsar. Dolayısıyla şimdi ve şu anla ilgili olmak üzere parça bütün münasebetini zekânın görevleri içinde saymak mümkündür. Şimdi ve şu anla ilgili olmak üzere zekânın anlam ve algı görevleri vardır. Kısacası zekânın, zaman bakımından gelecekle ilgili olmayan yani içinde bulunduğu an ile ilgili mantık, muhakeme, irtibatlandırma ve soyutlamasından bahsedilebilir. Şimdi ve şu an için görev yapan bir organın zaman bakımından kısa, orta ve uzun vadeli plânlarda insanlığın lehine isabet etmesi, tahmin ve tespitinin çok yüksek olması beklenemez. Nitekim zekâ ile ilgili bütün test veya ölçeklere bakıldığında özellikle en sık kullanılanlardan biri olması münasebetiyle Wechsler'in zekâ testinde, öğrenilmiş olanların yanı sıra buna benzer veya buna yakın işlemler olduğu gözlenebilir.

Çok zekî olanların veya zekâ seviyesi yüksek olanların hata paylarının az olabilmesi, akıl seviyesiyle ilişkilendirilebilir. Türk halk söyleminde "aklı kıt zekâsı çok" insanlar istikrarsız ve hatası çok, başarısız kabul edilen insanlardır. Hatta insanlardan övgüyle bahsederken "aklı başında" denilmesi o kişilerin etraflı analiz ve sentez yapabildiğini, vakur olduğunu ve gelecekle irtibatlı olarak isabetli fikirler sunabildiğini ifade eder. Bu hususu daha iyi açıklayabilmek için akıl kelimesinin kökenine bakmak gerekir.

"Dizginledi, gem vurdu, bağlandı, irtibatlandı, akıl süzgecinden geçti, akıl yürüttü" fiillerini ifade eden kelimenin kökü/mastarı olan "akl, aḳala (لقع)" kelimesi lisanımıza Arapçadan geçmiş ve esas itibari ile İbranicedir. Bu kelimenin İngilizcedeki karşılığını "reason" olarak ifade etmek mümkündür. Günümüz Türkçesinde kullandığımız akıl kelimesi ile İngilizce karşılığı olan "reason" kelimelerinin her ikisinin de bağlamak, irtibatlandırmak ve sebep sonuç ilişkisi kurmak anlamlarını taşımaları dikkat çekmektedir.

Akıl kelimesinin ilk kullanım anlamlarından olan "bağlamak" ifadesinin konu ile doğrudan ilgili olduğu söylenebilir. Buradaki bağlamaktan maksat birbirine uygun iki nesne veya iki kavram arasında bağlantı kurmaktır. Aklı zekâdan ayıran yegâne husus, en yakından sonsuz bir geleceğe doğru zekâya göre en az hata ile isabetli ve doğru bağlantıyı kurabilmek, fikrini bu bağlamda geliştirebilmektir. Geleceği yordayabilen fikre sahip olma konusundaki isabet oranına göre aklın seviyesinden veya derecesinden söz

Psikolojide Kavramlar ve Üstün/Özel (Zekâ, Potansiyel, Yetenek) Kavramına Psiko-Felsefî̀ Açıdan Bakış 
edilebilir. Bir başka ifade ile aklın en önemli özelliklerinden birisi şimdi ve yarınlarda birbirleri ile anlamlı ve uygun bağlantılar kurmayı başarması ve geleceğe emin adımlarla en az hata ile yürümesidir denilebilir.

Kültürel psikoloji açısından bakıldığında Türk kültüründe anonim olarak akılla ilgili aşağıda ifade edilen tekerlemede yön ve gidişatı belirleyen, anlamlı bağlantılar kuranın akıl olarak tespiti, akla yüklenen vizyonu ve misyonu çok güzel ifade etmektedir.

"İnsan bir gemi, / Akıl dümeni, / Kullan kendini, / Göreyim seni"

Gelecekle ilgili isabet etme, doğru yordamada bulunma konusunda Türk kültüründe iki çeşit akıl olduğunu Kutadgu Bilig'den biliyoruz. Bunlardan birisi "us" diğeri ise "ök" veya "öğ” diye ifade edilen akıldır (Başer, 2011). "Us" çok kısa süreli düşünebilen, olaylarla irtibat kurabilen, sebep sonuç ilişkisini temin edebilen ve aynı zamanda kısa süreli süreç yönettiği için yanılabilen, hata yapabilen akıldır. Genelde çocuklarda ve bilgisi yetersiz insanlarda bulunur. Onun için çocuklarla ilgili olarak Türk kültüründeki "Uslu dur azma, mezarını kendin kazma" hikmetli sözü çok meşhurdur. Bu ifadeden çocuklara "Afacanlık yapma! Dikkatli ve tedbirli davran! Duygularına göre hareket etme, aksi takdirde felaketlerle karşılaşabilirsin" anlamları çıkartılabilir.

"Ök" ise hata yapmayan, çok uzun süreli ve çok uzak gelecekle ilgili isabet payı yüksek yordamaları yapabilmenin yanı sıra zekâyı da doğru çalıştıran akıldır. Bir başka ifade ile zekâ akılla sıkı bir irtibatlı olarak ve aklın kontrolünde çalışır ise geleceğe yönelik, geleceği planlama, yordama adına hata payını azaltabilir.

Günlük dilimizde kullandığımız öğrenci, öğretmen, öğrenme, öksüz gibi kelimelerin -öğ kökünden türediği ifade edilmektedir. Öğrencinin hata ve yanılgısını asgariye indirebilmek için bilgi sahibi olmaya çalışan, gelecek için hazırlanan bir kimse olması; öğretmenin ise öğrencilerini bilgili yaparak, geleceğe isabetli hazırlayarak ve gelecek için yetiştiren bir insan olması; annenin ise çocuğunu her yönü ile bütün tehlikelerden koruyup kollayarak geleceğe hazırlaması "ök" sahibi olması yani yanılmayan veya çok az yanılabilen ve geleceği isabetle yordayan akıl sahibi olması ile bağlantılandırılmaktadır.

Ök kelimesini geleceği doğru yordayan akıl anlamında kullanan Balasagunlu Yusuf, on birinci asırda yazdığı ve soyut öğeleri somutlaştırarak anlatması yönü ile dünyada eşsiz bir eser olan Kutadgu Bilig kitabında dört tane karakteri canlandırır. 
Bu karakterler ve özellikleri şöyledir (Yusuf Has Hacib, 2007):

1. Kün Toğdı: Hükümdardır, adalet ve yasayı temsil eder.

2. Ay Toldı: Vezirdir, kutluluğu (saadet ve devleti) temsil eder.

3. Ögdülmiş: Vezir'in oğludur, aklı ve bilgiyi temsil eder.

4. Odgurmıs: Zahit, vezirin akrabasıdır, kanaat ve akıbeti söyler.

Kut bilgisinin oluşabilmesi için huzurlu ve mutlu bir şahıs ve toplumun oluşumunda, birini diğerine tercih etmeden adaletin, saadetin, kanaatin, akıl ve bilginin önemini ifade eder. Kanaat sahibi, akıl ve bilgiye önem veren, varlık sebebinin insanlığın huzur ve mutluluğu için olduğunu bilen ve bu yolda yürüyen, adaletle hükmeden insan, cihan padişahı olabilir. Balasagunlu Yusuf'a göre cihan padişahı, hiçbir kültürü, kültürün hiçbir öğesini asimile etmeden yukarıdaki özelliklerle yönetebilendir.

Görüldüğü üzere üçüncü sırada olan ve Ögdülmiş diye isimlendirilen şahıs aslında aklı ve bilgiyi soyut ve nitel anlamda temsil etmektedir.

Türk kültüründe olduğu gibi İslâm kültüründe de akıl zekâ ile beraber anılır ve zekâyı kontrol etme görevi vardır. İslam kültüründe de zekânın olduğu gibi aklın da dereceleri vardır. Günlük işleri ve maddî olayları yöneten akıl, zekâ ile ortak pek çok özelliğe sahiptir. Tek ayırıcı niteliği zaman açısından zekâdan ayrı olarak şimdi ve şu an değil, kısa bir süre de olsa gelecek içindir ve böyle bir akla "akl-1 maaş" denir. Bu akıl geleceği doğru ve isabetli yordama konusunda zekâdan bir adım öndedir. İç güdü, insiyak, sevk-i tabii veya gırîze kelimeleri ile ifade edilen ve ilkel akıl denilen yapının akl-1 maaşla benzer tarafları vardır ama akl-ı maaşla bunu aynı görmek mümkün görünmemektedir. Ancak asıl olan uzak geleceği doğru yordayan ve zekâyı yöneten "akl-1 mead"dır. Akl-1 meada, akl-1 selîm de denilmektedir.

Akl-1 mead veya akl-1 selimin en önemli ürünü; sahibini amaçlarına ve ideallerine/ülkülerine erdirmek anlamında düşünmek, fikir icat etmek veya daha doğru ifadesi ile derin bir tefekkür sahibi kılmaktır. Tefekkür Arapça "fikr" sözcügüünden türetilmiş; dalmak, düşünmek anlamlarında bir kavramdır. Türkçeye de oradan geçmiştir.

Tefekkür planlı, programlı, analiz ve sentezi yapılmış, geleceğe yönelik bir fikir üretme işidir. Tefekkür eden kimseye mütefekkir denilmektedir. Akıl ve fikir ile ilgili şöyle bir metafor yapılabilir: Tefekkür, akıl arsasına yapılan bir binadır. Nasıl ki yapılan binanın mutlaka önce ihtiyaçları gidermesi için ön çalışma yapılır, sonra planı-projesi çizilir, sonra imalat ve inşaat işleri devam ederse; bir fikirden bahsedebilmek için de böyle pek çok yönden sağlam zemine oturtulmuş, emek verilmiş, zahmet çekilmiş, analiz ve 
sentezi yapılmış, yöntemi olan bir faaliyetin olması gerekir. Yoksa burada bahsedilen fikir, günlük hayatın akışında olan/oluşan sıradan işleri organize eden anlamında değildir.

Bir başka metafor daha kurulabilir. Ziraatçılar bir buğday tanesinden birçok buğday taneleri üretebiliyorlar ise aynı şekilde mütefekkir/düşünür de belli bir kavramdan, birçok kavram üretebilir. Bir fikirden pek çok başka fikirler üretebilir. Ancak burada temel şart insanlığın lehine olmasını temin etmektir. Bunun için de önce doğru bilgi(!), doğru niyet ve doğru amacı temin etmiş olmak gerekir. Bunun yanı sıra bilinenden hareketle bilinmeyene ulaşmak da bunun için bir şarttır. Aksi takdirde tutarsız düşünceye tefekkür yani akl-1 selimin ürünü denilemez. Bir diğer metafor olarak akıl şayet bir makine ise fikir de onun çalışmasıdır, işlevidir (ürünü değildir). Nasıl ki çalışma makinadan ayrı düşünülemez ise aynı şekilde tefekkür de akl-ı selimden ayrı düşünülemez.

Akıl-1 selimin bilimsel fikir üretebilmesi için bir ön şart duyuların iyi çalışmasıdır. İdrak kelimesi akıl ve fikir kelimelerinde olduğu gibi lisanımıza Arapçadan girmiş ve erişmek, ulaşmak gibi anlamları içermektedir. Arapçada su çekmek için kuyuya sarkıtılan kovanın ipine derek denilmesi ve idrak kelimesi ile aynı kökte buluşması dikkatlerden kaçmamalıdır. Kuyudaki suya ulaşmak için kovaya bağlanan ip ve o suyu elde etmek isteyen insan arasında nasıl bir ihtiyaç ve ilişki varsa, bilgiye ulaşmak isteyen insan ve aklı ile bilimsel bilgi arasında da idrake öyle ihtiyaç vardır. Bu idrak yüzeysel beş duyu ile elde edilen bilgiden öte derin bir algı ve düşünce mahsulü olan üretilmiş bilgiye zemin hazırlayan idraktir. Bir başka ifade ile var olanların varlık sebeplerini bilip, var olanları var olma amaçları yönünde doğru kullanmak anlamına gelmektedir. Bu da tabiatın tahrip olmaması, insanların ve insanlığın aleyhine hiçbir üretimin yapılmaması anlamına gelir.

\section{Sonuç}

Sonuç olarak, günümüz psikolojisinde zekâ ve onun yakınındaki kavramlarda epeyce kavram karmaşası yaşandığı aşikârdır. Kavramları daha iyi anlamak için açıklandığı kültür perspektifiyle değerlendirmek ise bir hayli önem arz etmektedir. Dolayısıyla hem zekâ yelpazesindeki kavramların karmaşasına açıklayıcı bir bakış sunabilmek hem de bu kavram yelpazesini kültürel psikoloji bağlamında değerlendirerek kapsamını, yeterliğini ve derinliğini artırabilmek adına bu çalışmayla bir deneme yapılmıştır. Tek merkezli anaakım psikolojinin kavramlar adına sunduklarını değerlendirip, zekâ ile birlikte akl-1 selimi devreye sokarak psikolojiyi yeniden insanlığın 
bugüne kadar ürettiği tecrübelerden istifade edilen derin anlamlı, derin fikirli, derin idrakli ve akıllı hâle getirmenin gerekliliği gün gibi ortadadır.

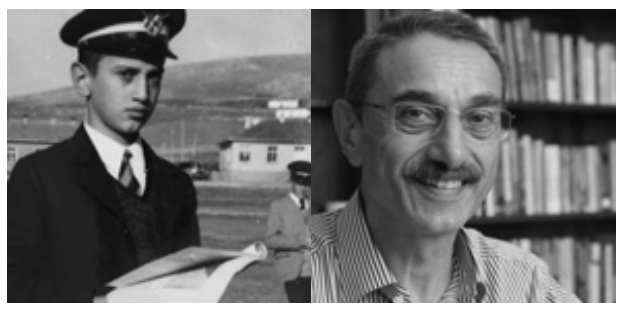

\author{
Osman Sezgin
}

\title{
Kaynakça
}

Bașer, S. (2011). Kut ve töre. İstanbul: İrfan Yayıncılık.

Budak, S. (2009). Psikoloji sözlüğü. Ankara: Bilim ve Sanat Yayınları.

Çaḡbayır, Y. (2007). Ötüken Türkçe sözlük. İstanbul: Ötüken Yayınları.

Doksat, R. (1975). Psikopatolojiye giriș. Adana: Cukurova Üniversitesi Yayınları.

Gardner, H. (2017). Zihin çerçeveleri: Coklu zekâ kuramı. İstanbul: Alfa Yayınları.

Keklik, N. (1982). Felsefenin ilkeleri. İstanbul: Doḡuş Yayınları.

Maher, B. A. ve Spitzer, M. (1998). Felsefe ve psikopatoloji. İstanbul: Gendaș Kültür Yayınları.

Morin, E. (1999). Seven complex lessons in education for the future. Paris: UNESCO Publishing.

Neufeldt, V. ve Guralnik, D. B. (1988). Webster's new world dictionary (4. baskı). New York: Simon\&Schuster Inc.

Özdemir, Ș. (2004). Bilgi Sosyolojisi Açısından “Doḡu” ve “Batı”. Uluslararası Illișkiler Dergisi, 1(1). 61-92.

Özekes, M. (2013). Peabody resim kelime testi 3.01-3.12 yaș aralığı İzmir bölgesi standardizasyonu çalıșması. Ege Eḡitim Dergisi. 14(1), 90-107.

Postman, N. (1994). Televizyon öldüren eḡlence. İstanbul: Ayrıntı Yayınları.

Sak, U. (2020). Üstün zekâlılar. Ankara: Vize Akademik Yayınları.

Schultz, D. P. ve Schultz, S. E. (2007). Modern psikoloji tarihi. İstanbul: Kaknüs Yayınları.

Sezgin, A. S. (2013a). 6-8 yas arası üstün ve normal çocukların yaș, zekâ ve duygu kontrolü-irade eḡitimi almıs olma baḡlamında karșılaștırılması. Yayınlanmamıș yüksek lisans tezi, İstanbul Bilim Üniversitesi.

Sezgin, O. (2013b). Eḡitimde psikolojik açıdan normale duyulan ihtiyaç, normalin ölçüsü ve çeșitleri. Kalem Eḡitim ve İnsan Bilimleri Dergisi, 3(2), 241-258.

Yusuf Has Hacib. (2007). Kutadgu bilig. Ankara: Türk Tarih Kurumu Yayınları. 